\title{
Article
}

\section{Sites of learning: Exploring political ecologies and visceral pedagogies of surplus food redistribution in the UK}

Spring, Charlotte, Adams, Mags and Hardman, Michael

Available at http://clok.uclan.ac.uk/25754/

Spring, Charlotte, Adams, Mags ORCID: 0000-0002-8949-1381 and Hardman, Michael (2019) Sites of learning: Exploring political ecologies and visceral pedagogies of surplus food redistribution in the UK. Policy Futures in Education, 17 (7). pp. 844-861. ISSN 1478-2103

It is advisable to refer to the publisher's version if you intend to cite from the work. http://dx.doi.org/10.1177/1478210318819249

For more information about UCLan's research in this area go to http://www.uclan.ac.uk/researchgroups/ and search for <name of research Group>.

For information about Research generally at UCLan please go to http://www.uclan.ac.uk/research/

All outputs in CLoK are protected by Intellectual Property Rights law, including Copyright law. Copyright, IPR and Moral Rights for the works on this site are retained by the individual authors and/or other copyright owners. Terms and conditions for use of this material are defined in the policies page.

\section{CLoK}

Central Lancashire online Knowledge www.clok.uclan.ac.uk

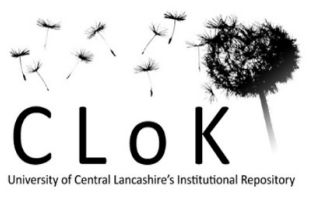




\section{Sites of learning: exploring political ecologies and visceral pedagogies of surplus food redistribution in the UK}

\begin{tabular}{|c|c|}
\hline Journal: & Policy Futures in Education \\
\hline Manuscript ID & PFIE-17-0160.R2 \\
\hline Manuscript Type: & $\begin{array}{l}\text { Special Issue: Eating in the anthropocene: Learning the practice and } \\
\text { ethics of food politics }\end{array}$ \\
\hline Keywords: & $\begin{array}{l}\text { food waste, food insecurity, food access, surplus food redistribution, } \\
\text { visceral pedagogies, political ecology of the body }\end{array}$ \\
\hline Abstract: & $\begin{array}{l}\text { Drawing on ethnographic research with organisations redistributing food } \\
\text { waste, this paper explores potentials for political and ethical learning by } \\
\text { comparing different approaches to food handling and teaching. Food acts } \\
\text { as instigator and tool for learning about ecological impacts, wellbeing, } \\
\text { food journeys, health, and pleasure. Re-learning wasted food challenges } \\
\text { accusations of its stigmatising potential while attempting to address } \\
\text { serious material issues of food insecurity and community food access. } \\
\text { Taking seriously the charge that 'community-level' approaches might } \\
\text { depoliticise and individualise food distribution at the expense of } \\
\text { structural critique and action, these pragmatic and polysemic enrolments } \\
\text { of food waste can nevertheless embody a teleology of change, through } \\
\text { changing practices of food handling and fostering critical understandings } \\
\text { of food system issues. While acknowledging the spatial, temporal and } \\
\text { technological mediators of foodstuff's journey between bin and mouth, } \\
\text { attention is paid to the sensorial, embodied, and affective means by } \\
\text { which the food/waste distinction is known and taught/learned. A 'political } \\
\text { ecology of the body' framework is used to explore the 'visceral realm' of } \\
\text { food access as always situated in learners' diverse former experiences. } \\
\text { These visceral pedagogies of knowing food sit alongside the power } \\
\text { dynamics of regulatory food governance in the form of, for example, } \\
\text { expiry-date labels. In short, these practices, albeit rooted in } \\
\text { environmentally damaging and unequally-distributed foodscapes } \\
\text { requiring systemic transformation, can nevertheless foster more vibrant } \\
\text { sympathies between people and food, more care-ful connections } \\
\text { between learners and their food futures. }\end{array}$ \\
\hline
\end{tabular}

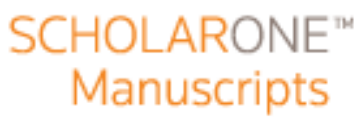


2 Title: Sites of learning: exploring political ecologies and visceral pedagogies of

3 surplus food redistribution in the UK

\section{Abstract}

6 Drawing on ethnographic research with organisations redistributing wasted food, this

7 paper explores potentials for political and ethical learning by comparing different approaches to food handling and teaching. Food acts as instigator and tool for learning about ecological impacts, wellbeing, provenance, health, and pleasure. Relearning wasted food challenges accusations of its stigmatising potential while

11 attempting to address serious material issues of food insecurity and community food

12 access. Taking seriously the charge that 'community-level' approaches might

13 depoliticise and individualise food distribution at the expense of structural critique

14 and action, these pragmatic and polysemic enrolments of food waste can nevertheless

15 embody a teleology of change, through changing practices of food handling and

16 fostering critical understandings of food system issues. While acknowledging the

17 spatial, temporal and technological mediators of food's journey from bin towards

18 mouth, attention is paid to the sensorial, embodied, and affective means by which the

$19 \mathrm{food} /$ waste distinction is known and taught/learned. A 'political ecology of the body'

20 framework is used to explore the 'visceral realm' of food access as always part-

21 situated in learners' diverse foodscapes. These visceral pedagogies of knowing food

22 sit alongside the power dynamics of regulatory food governance in the form of, for

23 example, expiry-date labels. In short, these practices, albeit rooted in environmentally

24 damaging and unequally-distributed foodscapes requiring systemic transformation,

25 can nevertheless foster more vibrant sympathies between people and food, more care-

26 ful connections between learners and their food futures.

27 Keywords: food waste; food insecurity; food access; surplus food redistribution;

28 visceral pedagogies; political ecology of the body

31 The growing prevalence of schemes to intercept and redistribute food wasted by

32 producers and retailers has responded to, and further problematised, not only the

33 extent of food wastage in wealthy food economies, but also the uneven distribution of 
34 wealth and food access manifest in growing evidence of 'household food insecurity'

35 (Midgley, 2013). Attention to food insecurity in UK media, civil society organisation

36 (CSO) and policy discourse has renewed concerns over its prevalence in schools e.g.

37 All-Party Parliamentary Group on School Food (2015). As charitable food banking in

38 the UK has expanded, CSOs and community groups have increased provision of

39 holiday-period food assistance. Additionally, the growth of school breakfast provision

40 suggests schools' widening role in children's foodways. This paper highlights

41 ambiguous implications of a food waste activism network's school food programme.

42 Its pedagogical practices raise questions around a two-fold concern. Firstly, the role

43 of community organisations in responding to systemic problems; namely food

44 insecurity and food wastage. Do locally-grounded charitable and activist responses to

45 food inequalities risk depoliticising or deflecting structural causes and solutions?

46 Secondly, 'surplus food redistribution' in schools raises questions about children's

47 responsibilities over their own food choices. How does the summoning and

48 cultivation of childrens' embodied and sensory capacities to know food differently

49 affect, on the one hand, their health and food access and, on the other, their

50 responsibilisation for systemic issues lying beyond their control? Through the

51 framework of a 'political ecology of the body' (Hayes-Conroy, 2015), and

52 specifically the notion of 'visceral access', binary notions assumed by these questions

53 will be challenged: 'charity v activist' frames of surplus food redistribution, and

54 'agency v structure' binaries assumed by the question of whether food waste

55 pedagogies empower or responsibilise young people (the verbal form 'wasted' rather

56 than 'surplus' food is adopted, conveying human-induced processes by which food is

57 rendered waste). These questions will be explored through two empirical cases;

58 primarily, a school programme using wasted food intercepted by a network of

59 redistribution activists, and a charity that redistributes food similarly to a US-style

60 foodbank. First, literature considering the political implications of food provision and

61 pedagogies in schools are explored.

\section{Knowing food as more-than-food}

63 Food is an ontologically-multiple medium for learning about the politics and ethics of

64 food systems. Biltekoff (2016) analyses 'framing contests' at play in the design of

65 school curricula by food activist and food industry bodies. These aim to shape

66 "different kinds of consumers" but also to "stabilize different versions of what food 
67 is" (2016:55). Biltekoff compares polarised articulations of processed food, where

68 'Real Food' (a discussion guide by sustainable food activists) frames food as

69 "connections across natural and social systems" (2016:53), while 'Real Facts' (a food

70 trade association's education materials) frames food not as systemic and political but

71 ontologically 'singular': a commodity delivering consumer needs and producer

72 profits. Biltekoff distinguishes ontologies of health inhering in the curricula: Real

73 Food "decentres the individual" and highlights issues of "access and policy"

74 (2016:52-3), while Real Facts' "anti-politics of health...frames and enables health as

75 the result of individual biology, personal responsibility, and information" (2016:54).

76 Advocating dialogic research that recognises food system problems and solutions as

77 technical and social, her analysis reveals how food pedagogies differently construe,

78 responsibilise and/or empower children and their foodscapes. The following section

79 introduces another approach to understanding foodscapes as ontologically multiple.

\section{$80 \quad$ Political ecology of the body}

81 Hayes-Conroy's (2015) political ecology of the body (PEB) framework encompasses

82 analytical attention to structural, discursive and material dimensions of health and

83 wellbeing. Its hybrid foci mirror shifts in political ecological thought from situating

84 ecological struggle within political economic constraints towards embracing post-

85 humanism (Heynen, 2013). PEB builds on feminist critiques of social constructivism

86 in highlighting affect, materiality, embodiment, emotion, performativity and non-

87 representational methodologies for grasping life-as-lived. Bodies and eating offer

88 vantage points for understanding food as the material grounds of survival, structural

89 enabler and constraints of this, and discursive practices mediating food access at

90 multiple scales. Considered through a PEB lens, everyday work of food redistribution

91 involves agentic encounters with food items, ideas about that food and more or less

92 explicit engagement with structures that both enable and constrain practices.

\section{Visceral food access}

94 Hayes-Conroy (2017:51) writes that theoretical attention to 'the visceral realm' seeks

95 to understand political agency "from the body out". By 'visceral' she denotes the

96 "state/feeling of bodies in interrelation with environments/space". As a specifically

97 political pursuit, we must not only 'follow' bodies but also "experiences of social

98 position(ing), norms and difference". This includes methodological reflexivity in 
research praxis, including attending to race, class and gender. Hayes-Conroy \& Hayes-Conroy (2013) apply the framework to school cooking-and-gardening programmes. They acknowledge diverse "visceral topographies" that individual learners bring to learning encounters. Bringing students into relation with new foods and ideas can "widen the scope of emotional possibilities" (2013:84) and (re)shape material sensitivities, identities and relationships available to them. However, learners' different backgrounds and experiences may engender frustration or resentment towards programme interventions: hoped-for outcomes depend on contingent and haphazard encounters between teachers, learners and more-thanhuman mediators. The authors' notion of 'visceral access' acknowledges bodily senses and motivations as micro-spaces of encounter. Children's "specific bodily histories and prior and current affective/emotional relations with alternative foods" (2013:82) comingle with embodied sensations of food handling and eating to (re)shape visceral access, body-food relationships and encounters whose consequences can stretch beyond the classroom.

PEB's attention to children's life-assemblages highlights school as just one node in 'foodscapes' (Brembeck et al., 2013) and the importance of recognising food choice as a more-than-individual matter comprising families, homes, shops and sensory experience. This takes us beyond the precepts of 'sensory education', which aims to teach children to eat healthily through making novel/healthy foods sensorily familiar e.g. Reverdy (2011). By critiquing socio-environmental change premised solely on 'attitudes, behaviours and choices' of individuals (Shove, 2010), PEB can attend to micro-level food-body assemblages as well as how food redistribution organisations address, or neglect, broader issues of political responsibility for hunger and waste. I now turn to consider political modalities of such redistribution.

\section{Community feeding programmes: revolutionary possibilities?}

Ethnographies of wasted food redistribution, and community feeding programmes more broadly, reveal its complex ethico-political implications, often relying upon a binary distinction between activism and charity. Heynen (2010) contrasts the political containment functions of charitable food with radical forms of food redistribution that, historically, have contested uneven "geographies of survival". 
130 Patel (2011) analyses conditions transforming food assistance from 'pacifying to 131 revolutionary' in the Black Panther Party (BPP)'s politics of the everyday. The BPP

132 exemplifies political possibilities in everyday, material mechanisms of social

133 reproduction, including community food programmes. Its 'Free Breakfast for

134 Schoolchildren' programme was launched in 1968, feeding thousands of children

135 across America at its peak (Heynen, 2009). It addressed corporeal realities of uneven

136 urban food access given state failures to meet basic biophysical needs of African-

137 Americans. Importantly, such 'survival programmes' were explicitly recognised as

138 "not solutions to our problems", but to nourish "survival pending revolution" (Huey

139 P. Newton Foundation, 2008:4). Grounding politics in everyday bodily survival and

140 creating spaces/relationships of mutual aid, Heynen argues, was necessary for broader

141 solidarities to emerge. Neighbourhood care networks could extend to national-global

142 assemblages of solidarity, stretching the concept of 'community'. This challenges

143 binary interpretations of whether 'community-level' praxis enables or constrains

144 systemic political change at multiple scales.

145 Patel (2011:122-3) distinguishes the BPP's “vision for social change” from charity:

By bursting the idea of food as...charity bestowed by rich to poor, setting in its place the notion that food is a right- and...that an order might be composed without private property- the act of feeding children was transformed from pacificying to revolutionary (p.25)

This transformation is rooted in nurturing material geographies of everyday survival and, Heynen (2009) argues, challenging the patriarchal dissociation of revolutionary praxis from domesticity and care. The BPP's breakfast programme appears in dialectical light, where food nurtured bodies, ideas and communal spaces as a necessary (if insufficient) vehicle of broader systemic transformation that nevertheless instigated considerable structural change. Pressure on Hoover's government as a result of BPP activism led to the breakfast programme's co-optation in the rollout of federally-funded school breakfast programmes (Patel 2011). Such articulations of practical action and political organising suggest counter-possibilities for community food programmes to engender multi-level change, for bottom-up organising to foster systemic change, albeit in unpredictable ways. While operating in a different context, UK schools are increasingly recognising impacts of food insecurity among families on young peoples' learning (Joseph Rowntree Foundation, 2017). Where state entitlements have declined, living costs have risen and employment does not 
164 necessarily protect against poverty. In this context, can wasted food redistribution, 165 and the politics it generates, foster systemic change while addressing bodily needs?

166 Debates are underway in the UK as to the kind of solution 'surplus food

167 redistribution' offers as a response to hunger and/or food waste, and its distribution of

168 benefits (Caraher \& Furey, 2017). The following section explores redistribution as

169 contesting commodification as a vector of edible food's unnecessary wastage.

170 Eating waste as affective activism

171 Critical food waste scholarship analyses the commodification of food's cosmetic

172 qualities as an aspect of systematic wastage. Commodification facilitates wastage if

173 foodstuffs' exchange value is not realised. Giles (2016) analyses "postcard-perfect"

174 rows of produce in Seattle's Pike Place market as "meta-signifiers" of world-class

175 consumption, exuding an "anthropocentric cosmopolitanism, diametrically opposed to

176 the contingency of a natural world which resists the ontological standardisation of

177 form and function inherent in the commodity" (Giles 2016:84). Theories of affective

178 politics, such as Thrift (2004) on "the manipulation of affect for political ends", can

179 help to account for wasted food's materiality, including the moral discomfort and

180 visceral feelings its presence often prompts. What matters in food's aesthetic

181 festishisation is not the capacity of food-commodities to nourish bodies and uphold

182 subsistence rights, but the logics of capital accumulation, premised on the routine

183 expulsion of 'ex-commodities' (Barnard, 2016). Understanding food's wastage for

184 commercial reasons regardless of its edibility leads social movement activists to

185 acknowledge, articulate, and challenge this logic, demonstrating use values by eating

186 recovered food and bequeathing it an alternative biopolitical trajectory from its

187 commodity form.

188 Barnard notes the conflation between waste's symbolism and its visceral capacities,

189 arguing that "we are now frequently disgusted by anything labelled 'waste"”

190 (2016:129). For 'freegans' in his study, eating 'polluted' food attempts to

191 symbolically "flip the object of disgust onto the companies that created ex-

192 commodities in the first place" (ibid.). Freegans refracted the 'dirt' of wasted food by

193 visually displaying 'dumpster-dived' foods on sidewalks with speeches decrying the

194 capitalist logics and socio-ecological harm represented by food wastage to passers-by.

195 Patel (2011) notes how the BPP obtained breakfast programme foods from the San 
196 Francisco Diggers, whose redistribution of wasted food as free public meals

197 constituted a prefigurative politics of demonstrating alternatives to capitalism. The

198 BPP framed their reliance on donated food as a way for businesses to express

199 community care. They envisaged businesses lowering their prices given their analysis

200 of capitalist "robbery", the "ridiculously high prices that we must pay for food, which

201 is necessary for our daily sustenance" (Huey P. Newton Foundation, 2008:39).

202 Contrastingly, Barnard and Mourad (2014) explore how superficially similar acts of 203 redistributing surplus food can enact divergent political repertoires that may or may 204 not be understood/shared by eaters. Food's politicised redistribution bears a long 205 history; activists' analyses of its commodification and material possibilities suggest 206 discursive repertoires that can be compared with the empirical cases explored in this 207 paper.

\section{Reconfiguring the senses}

209 Theorising the activism of Food Not Bombs, Giles argues that food commodities'

210 "material agency" as ripening or bruising amounts to corrupting trajectories towards

211 "matter out of place" that renders food (commercially) waste (2016:84). Barnard

212 notes the dominance of the visual in determining food's status:

The fetishism of waste partly comes through our overreliance on sight and misconceptions about hygiene; by adopting new practices and norms, freegans were prefiguring a "post-fetish" world (2016:130)

216 For activists, food recovery means more than material survival, enacting "direct

217 action that challenged the power of retailers to determine what was, and was not, 218 good to eat" (Barnard 2016:127). This prompts us to consider who and what else 219 might have the power to determine what is good to eat, and how. Wasted food's 220 structural, representational and material qualities can be re-configured through 221 practice, and it is practices of food acquisition, handling and teaching that will be 222 considered in relation to the school programme's politics.

223 Here we see opportunities for a PEB analysis of food redistribution practices,

224 considering multi-bodied affect as well as the politics of representation and 225 knowledge-production around food/eating. Structural forces of different natures and 226 scales are acknowledged, for example the role of regulation. US reluctance to 227 legislate for standardised expiry-dates, Barnard argues (2016:127), reflects corporate 228 interests, which "make more money when consumers don't trust their senses and 
229 throw out food that has passed a conservative sell-by date". For freegans, challenging

230 expiry-dates and commercial cosmetic standards to distinguish food from waste

231 involves the cultivation of embodied discernment of food via the senses. The

232 embodied knowledge politics through which edibility is conferred by engaging

233 sensorily with food thus serve as a means to critique government inaction and

234 corporate greed.

\section{Food safety as praxis}

236 Barnard notes that freegans, ironically, actually know little about where their food

237 comes from and that food may have been wasted because it is unsafe, such as product

238 recalls (Barnard, 2016:128). Food's potential to make people ill constitutes valid

239 anxiety that can hasten food's categorisation as waste in homes (Evans, 2014:47).

240 Freegans' risk-minimisation strategies included careful procedures for washing,

241 preparing and cooking food. One way to compare the politics of food redistribution is

242 thus to examine how different redistributors negotiate ideas, devices and practices for

243 determining wasted food's suitability for feeding to people. Rather than objectively

244 judge food as 'safe' and 'edible', the task here is to analyse redistributors' mediations

245 for knowing good food, and for teaching this to others, which will be later analysed in

246 challenging binary distinctions between redistribution-as-activism and redistribution-

247 as-charity. The next section examines literature critiquing the latter.

\section{Charitable food redistribution}

249 Unlike activists' de-fetishisation efforts, wasted food provides a vehicle for 'doing

250 good' by charitable organisations, not primarily to critique causes of food wastage,

251 but to feed food-insecure people. North American literature suggests important

252 distinctions between transient, subcultural redistribution by social movements as

253 described above, and institutionalised charitable redistribution. Poppendieck (1998)

254 roots the latter in chaotic origins of utilising food surpluses to provide a temporary

255 solution to the poverty wrought by Reaganomics. This expanded to become highly-

256 resourced, integrated and professionalised foodbanking networks. These, she argues,

257 oversimplify and depoliticise poverty through "cosmetic solutions", redefining the

258 retrenchment of public entitlement as individualised hunger that can be solved by

259 gifts of food (1998:315). 
260 UK debates around responsibilities of government, charity and corporations in 261 addressing poverty through food redistribution have intensified since the onset of 262 post-recessionary austerity Conservative Party policy-making in 2010 (Midgley, 263 2013). Critics have questioned the quality and appropriateness of charitable food 264 (Caraher \& Furey, 2017). Power imbalances implied by Patel's description of charity 265 as 'pacification' have been analysed in terms of stigma, shame and powerlessness 266 (van der Horst et al., 2014). While uneven emotional and affective dynamics of food 267 aid encounters have been explored (Williams et al., 2016), less attention has been paid 268 to the visceral realm of wasted charitable food. Critics have, however, shed light on 269 the qualities of donated and wasted food; Tarasuk and Eakin (2005) noted the "limited 270 and highly variable supply of food donations" as a limiting factor of foodbank 271 provision. Van der Horst et al. (2014:1512) note that for some recipients the 272 "experience of poverty is heightened by the content of the food parcels", including 273 regular inclusion of "spoiled food" where expiration dates prompted emotional 274 responses to "embodied taboos" around eating 'waste'. Recipients were expected to 275 "overcome...inhibitions" (ibid.) through volunteers educating them about the 276 relevance of expiration dates. This contrasts with the discursive refraction by which 277 freegan activists re-framed food as edible and desirable by challenging 'embodied 278 taboos' around expiry-dates as regulatory constructions, not as flawed individual 279 knowledge.

\section{Political food ecologies: challenging the activist/charity binary}

281 Before turning to our methodology, we bring together some of the strands laid out in 282 identifying a nexus of food politics, ethics and pedagogy that blur the distinction 283 between pacifying and revolutionary. The PEB framework critiques efforts to teach 284 'ethical' food to students whose classed, racialised and gendered 'visceral 285 topographies' may be obscured by pedagogical programmes that aim to broaden 286 learners' foodscapes without acknowledging the structural, representational and 287 material constraints affecting all teaching and learning (Hayes-Conroy and Hayes288 Conroy, 2013). Critiques of the individualising propensities of charitable 289 redistribution (Poppendieck 1998) can nevertheless be applied to more radical 290 redistribution practices. While 'dumpster diving' for some provides a means to 291 disavow waste resulting from strict cosmetic standards, conservative expiry dates and 292 abundantly-stocked shop shelves, its positing of individual practice in pursuit of more 
293 ethical forms of consumption arguably misses the "extent to which these practices are

294 constrained by the existing organization of food production, distribution and

295 consumption” (Mourad \& Barnard, 2016).

296 The PEB framework, however, embraces the interactions of the structural, discursive 297 and material operations of power and we consider political activity at multiple levels, 298 rather than analyse all consumption-focussed activity as embodying neoliberal 299 strategy. We will thus explore different ways that redistribution organisations 300 configure food qualities, especially safety and edibility, and their political 301 implications. Exploring differences between organisations' more-than-human 302 assembling of food ethics is an attempt to identify spaces for debate around a key 303 question for food justice: how should we regard/utilise wasted food?

304 As suggested, actors utilise wasted food for different ends, using diverse practical and 305 discursive means for representing and handling food/waste, which translate into 306 distinctive pedagogies of 'knowing food' that can then be taught to others. These 307 range from activists' performances revealing the extent and mundane capitalist logics 308 of food wastage to expanding charitable movements framing wasted food as a 309 resource for addressing poverty. While reflecting distinct political repertoires, they do 310 however overlap and converge in important ways: their reliance on donated food, and 311 their enabling of food access through re-diverting flows of decommodified food. The 312 everyday work of redistribution involves agentic encounters with food items, ideas 313 about that food and more or less explicit engagement with structures that both enable 314 and constrain practices. Patel (2011:129), however, argues that the difference between 315 'pacification' and 'revolution' lies in the recognition that food provision is not enough 316 to transform food injustices, which requires envisaging and acting upon the scale of 317 injustice through "political education and effective action". He also notes the 318 importance of grappling with gender, race and other intersectional vectors of 319 inequality in the pursuit of radical change. Might UK food redistribution offer a 320 politics of empowerment, solidarity and critique rather than pacification, the 321 disciplinary function served by charities in the neoliberal rollback of redistributive 322 policy (Poppendieck, 1998)?

323 In conjunction with theory laid out, our empirics will challenge the activist/charity 324 binary by highlighting differing redistribution organisations' mutual concerns, 
325 challenges and role in an expanding field of food aid. A focus on sensory praxis will

326 draw out this challenged binary by examining pedagogies of teaching food/waste

327 distinctions by two organisations, and by considering how organisations attempted to

328 provide food that was appropriate, desirable, and safe.

329 Methodology

330 Having situated our study in analyses of wasted food redistribution for diverse ends,

331 we introduce the redistribution projects studied. The main focus is the school-

332 educational programme of a network of pay-as-you-feel cafes serving wasted food. Its

333 initial aim was to protest food waste's environmental hazards by demonstrating its

334 extent and needlessness, but several participants also highlighted the network's role in

335 bolstering food access in deprived neighbourhoods. Food is generally acquired

336 through local businesses donating surplus food rather than bin-diving, though activists

337 describe donations as 'interceptions' in a politics of refusal to acknowledge the

338 beneficence of the food industry whose profit-motivated excess, they argue, causes

339 wastage. Receiving donations also minimises risks of redistributing unsafe food,

340 which Barnard (2016) notes is a risk of freegan practice.

341 The programme delivers wasted food to schools, which is subsequently redistributed

342 to families through pay-as-you-feel market stalls manned by parents, teachers and/or

343 children. It aims to alleviate school hunger (e.g. providing morning toast in

344 classrooms) while raising awareness of food wastage. It was co-founded by a school

345 in an area of high deprivation in a city in the north of England, described by the co-

346 ordinator as a "desert" of access to both food and service provision. Organisers lead

347 assemblies and classes to teach children about health, sustainability and

348 entrepreneurship through handling wasted food. The programme also aims to

349 contribute to the network's campaign strategy, "empowering" children to "feel like

350 they have the power to be an activist", as one organiser described. Its aims thus go

351 beyond providing inexpensive foods to families. Further, it hopes to instil changes in

352 children's attitudes and skills around food that it is hoped will help them prevent food

353 waste in their own and others' lives. Research, undertaken from 2015-2016, included

354 a year of participant observation and semi-structured interviews with ten members of

355 the pay-as-you-feel cafe network, including school programme organisers (referred to

356 as 'activist-educators' below). Ethical and time considerations precluded interviewing 
357 children/parents, so interviews aimed to capture organisers' experiences in relatively

358 early stages of the programme.

359 The school programme's approach is compared with a national charity redistributing 360 wasted food with the explicit aim of alleviating 'food poverty'. It redistributes food

361 from major industry partner-donors to local charities through an expanding

362 infrastructure of warehousing and transportation. It must adhere to the national

363 charity's food-safety guidelines. Fieldwork took place over one year from November

3642015 , with one regional depot.

365 Ethics approval for the research was granted by the university and informed consent

366 granted by organisers and participants in all locations. Interviews were recorded,

367 transcribed and analysed, drawing on tools of Critical Grounded Theory (Belfrage \&

368 Hauf, 2017) which facilitates attention to structural, discursive and relational/material

369 dimensions. The two organisations' distinct origins, relationships with donors and

370 modes of redistributing food offer ways to consider the political import of differing

371 approaches to distinguishing food from waste through embodied praxis.

372 School-based redistribution: depoliticising or meeting immediate needs?

373 The first question to be addressed empirically is whether community-level food

374 assistance depoliticises structural issues of poverty and waste. Heynen's (2009:408)

375 reminder of the under-theorised mundane, "horrifying reality of hunger" situates

376 urban hunger "within the context of political economy, social reproduction, and

377 poverty". Projects attending to this can thus provide not just vital sustenance but a

378 window onto spatial and structural determinants of hunger. The activist network

379 expressed attention to these, as shown below. Most pay-as-you-feel café network

380 members differentiated themselves from charitable food aid providers, highlighting

381 their primary purpose as campaigning against food waste. One characterised the

382 redistribution charity's donor relationships as "so far up Tesco's arses that they'll

383 never campaign to end food waste" (interview, café organiser, 19/1/16). She

384 nevertheless described differences between cafés' emphases on addressing hunger

385 locally, a point verified by other interviews, suggesting a mutual concern with the

386 charity.

387 While the wider network tended to downplay its hunger relief role, the school

388 programme (just one of the network's multiple conduits for redistributing surplus 
389 food) cites alleviating in-school hunger as a primary aim. The founding school is 390 located in area categorised as in the "bottom 2\% of deprivation nationally" (Joe, 391 school staff, interview 25/10/16). Joe described it as a "food desert", with the local 392 supermarket 2.5 miles away. With most parents lacking a car, the $£ 5$ cost of taxis and 393 buses to the shops meant less money to spend on healthier foods. The "medium of 394 food", Joe suggested, was a means to engage parents in the school community, 395 including its provision of English lessons, housing and welfare services. With over 396 forty languages spoken by the school's families, he acknowledged multiple forms of 397 deprivation affecting the school's refugee and asylum-seeking families. Joe's analyses 398 reflect sensitivity of school staff to the structural determinants of hunger affecting 399 pupils in their familial and geographical contexts. Staff have, alongside the activist 400 network, advocated for income-based solutions by participating in national campaigns 401 to address school-related hunger.

402 However, everyday activities raise questions about the appropriateness of surplus 403 food market stalls, even if situated in broader political discourse. Food deliveries to 404 schools are pre-sorted by volunteers of the café/activist network to ensure no high405 risk food (bearing a 'use-by' date or needing refrigeration) is included. Schools 406 receive a mixture of fruits/vegetables, bread/"cereal-type items" and "treats". While 407 the network has secured enough donors to allow some predictability, and families are 408 able to choose what to take, supplies are still dependent on available surpluses and 409 can reflect the highly-processed, highly-packaged products one often encountered in 410 redistribution spaces throughout the research. The 'market' is not intended to meet 411 families' full food needs, and schools may use food internally for classroom learning 412 or morning toast. While boosting food access, the stall nevertheless offers a partial 413 and contingent source of food rather than fulfilling the human right to food, a 414 challenge similarly levelled at charitable foodbanking (Tarasuk \& Eakin, 2005).

415 The pay-as-you-feel model of accessing food was noted in some interviews to be 416 confusing and even frustrating for certain 'shoppers', prompting questions around the 417 nuances of re-marketising food in school settings. Intended as a redistribution model 418 that does not require referrals to foodbanks and is thus available to anybody, it 419 nevertheless re-confers an exchange value onto food where the normative mode of 420 paying is with money (rather than 'skills or time', which the organisation also invites 421 as means of paying). In line with Barnard and Mourad's (2014) argument that food 
422 waste activists' political repertoires may not be apparent to those receiving the food,

423 the market stall could become seen as just one more node in an expanding network of

424 charitable feeding. These points suggest the capacity of schools to bolster

425 communities' access to food and other services, but also the latent disciplinarity of

426 this extension of pastoral care to parents and the wider community. Engaging parents

427 in the job-searching, financial literacy and upskilling techniques of austerity

428 Workfare-style contemporary welfare through the 'medium of food' suggests a need

429 for critical attention to responsibilities of the state, through schools, in providing

430 welfare services. Little evidence appeared from initial interviews of a coordinated

431 political strategy that engaged families, schools and activists, without which Patel

432 (2011) suggests food distribution can remain 'pacifying', leaving structural

433 determinants of hunger/waste largely unchallenged.

434 How does the redistribution charity's model compare? First, it delivers food to a range

435 of organisations whose varied political work can be seeing as "flying in under the

436 cover" of the charity, as Henderson (2004) skilfully argued of the articulations

437 between depoliticised charities and those they serve. Interviews revealed a diversity

438 of workers' beliefs about structural causes of hunger/waste, and motivations to

439 address these. Fundamentally, however, the charity's key priorities were upholding

440 donor relations, expanding infrastructure and regulatory compliance priorities, not

441 campaigning. While workers learned about problems including school hunger and

442 geographical deprivation through their articulations and engagements with recipients,

443 the charity's key remit remains alleviating need through food provision, not structural

444 change.

445 We now turn to examine the visceral pedagogies through which wasted food was

446 (re)configured through experiential learning, using the PEB framework to consider

447 such learning on the de/politicisation spectrum outlined in Biltekoff's (2016) analysis

448 of curricular design.

\section{Viscerally learning food}

450 As noted, the 'curation' of schools' food deliveries at the redistribution network's

451 warehouses yields some consistency in type/quality and may prompt questioning

452 among children as to why visibly-edible food has been thrown away, and what might

453 be done with it. Pupils' receiving and re-sorting food for their market stall entails 
454 visceral engagement with food. By handling and exploring its affective qualities, 455 food's designation as 'waste' can thus be reconfigured. Food thus arrives at the school 456 as ontologically plural, as not simply a commodity or nourishment, but the result of a 457 systemic journey of wastage and recovery, as explained in tailored classes.

458 Activist-educator Tim designed lessons to challenge 'embodied taboos' around, for 459 example, past-dated food. He described a pupil complaining that the food was "just 460 manky bananas", so planned an initial lesson to

Playful tactility prompted disgust reactions: the manky banana comment; they think that it's just gonna be out-of-date food. (Tim, activist-educator, interview 26/10/17)

I take a squishy banana, one that's slightly bruised...and get them to pass it around...it's like a hot potato, like urgh, urgh, and they want to pass it on as quickly as possible (Tim)

Disgust was then challenged through preparation practices, re-tooling the 'manky' banana by blending it into a smoothie for everyone to taste. Such touch-sight-taste reconfigurations provided visceral opportunities to (potentially) counter preconceptions. Contrasting effects of food on visual and gustatory receptors provide potential openings/blockages in the holistic assemblage that is motivation to try foods.

473 These learning encounters create shared spaces for children's diverse 'visceral 474 topographies' to be re-traced, perhaps challenging visual and haptic food judgements 475 through food practices and tasting.

\section{Fostering 'healthy' connections with food}

477 Handling less-than-perfect foods was thus intended to widen children's affective 478 repertoires with food. Educators aimed to foster bodily habits of engaging with food 479 to be better able to discern, sense, and appreciate food's qualities: as edible, healthy, 480 desirable. Fruits and vegetables were frequently mentioned as suited to sensory 481 learning, suggesting the programme's alignment with dominant curricular concerns 482 around 'healthy' eating. However, foods were re-contextualised as connective actants 483 in food systems where 'health' emerges relationally rather than residing in individuals 484 (Biltekoff, 2016). During an activity where children tried to place food in familiar 485 categories, Nik re-positioned children's surprise at learning cucumbers as fruit within 486 a narrative of food-plants' teleologies: 
We talk about... actually what's a fruit for...if you understand [that] then you'll understand why it's very nutritious 'cause the whole point of the fruit is to feed the little seedling and so it's all about making those connections about actually, this is not just something that you put in your mouth and it tastes a certain way, it might grow a bit or whatever else; there's a whole lot more to it...(Nik)

Nik thus reframed fruit as more-than-food: a relational "material-semiotic actor" (Haraway, 1988) whose 'job' is to do more than feed humans. Here, multi-sensory engagement implied more than intensified sensory receptivity, by layering cognitive knowledge about food with immediate sensation.

\section{Co-creating knowledge?}

Biltekoff notes how the 'Real Food' curriculum cast pupils not as passive recipients of knowledge but as co-creators of learning rooted in their broader foodscapes. While Tim acknowledged children's preconceptions, activist-educator Nik framed children's prior food knowledge as lacking: "before I go into the classroom, if you ask someone where food comes from, it comes from a shelf in a shop and before that it becomes a bit of a...dark grey hole". Learner-subject's 'grey holes' suggest blank slates for the inscription of food systems knowledge. This masks somewhat the complexities of children's prior ways of knowing food, perhaps the materiality of past shopping trips, and partially obscures the co-constructive, contestable nature of learning given children's diverse 'visceral topographies'. However, one organiser mentioned parents being invited to food waste assemblies, suggesting attention to children's wider foodscapes, and the relationships that populate them.

\section{Sensing food/waste}

Foods' changing qualities as they degrade were instrumentalised to reconfigure assumptions about food-as-waste using visual, olfactory and even auditory cues.

Children were encouraged to suggest how they might use different sense modalities to determine whether food is "good to eat":

There'll usually be one person who knows about tapping a melon...every sense will have a...relevant application to understanding whether the food is ripe or rotten (Nik)

Mushrooms' “stink" prompted giggles, prompting Nik to recast disgust reactions through re-framing the mushroom as a "fungal fruit". Yellowing broccoli was re- 
describing food were thus presented, aiming to widen children's acceptance of imperfect food as potential nourishment but also ecologically conscious consumption.

\section{Situating food safety}

523

Activist-educators aimed to teach food safety as a contextual matter of interpretating regulatory determinants of waste. Improving expiry-date literacy has been an aim of government research and behaviour-change programmes around food waste (Lyndhurst, 2008). One organiser asked children to discuss their understanding of different expiry-dates:

What it does is create confusion, and that's probably the best word to describe how dates work on food in this country, confusion...(Tim, 26/10/2016)

After explaining differences between 'use-by' and 'best-before' expiry-dates (Milne 2012), children were encouraged to consider them in context:

We use the example...if there's two pieces of meat...one's been stored in the fridge, one's been out in the sun- they're both still within the use-by date- can you eat them both? (Tim)

He reported that most children would reply "yes", suggesting primacy of the expirydate as a mode for interpreting edibility. He would tell them:

$$
\begin{aligned}
& \text {...'no, you can't, because it hasn't been stored correctly, and actually you don't } \\
& \text { know how your food's been stored up to the point you get it'... we're really } \\
& \text { pushing that confidence and use of their senses as much as they can...(Tim) }
\end{aligned}
$$

Contextual re-presentation aimed to destabilise the expiry-date's authority and 'push' different kinds of confidence, by enacting sensorial, emotional and situated knowledge (Haraway, 1988).

Food regulation has often followed crises of public trust in food systems following 'scandals' rooted in intensive production (Milne, 2012). Contra the scientific expertise congealed in expiry-dates, activists' beliefs that such technologies arbitrarily contribute to unnecessary waste prompted other kinds of knowing to take precedence in their pedagogies of knowing food:

...[sensory engagement]'s also an alternative way to understand when something's still good to eat- that if you don't want to look at that stupid date then what do you do then? (Nik)

Activist-educators did account for children's diverse prior knowledge. Nik suspected that children knowing precisely what different dates mean was "informed by a family having to do that [eat past-date foods] rather than having made the ethical choice but 
554 informed by not really having that much money to spend", while other children

555 expressed "overly strict behaviour around dates". While describing expiry-dates as

556 'stupid' expresses frustrated belief that they cause unnecessary waste, educators thus

557 recognised the limitations of individualising children's behaviour given its rootedness

558 in their variable foodscapes and the ways thriftiness may well already figure highly in

559 families' strategies to cope with food insecurity.

560 Charitable food: date-adherence as preserving dignity?

561 How does the redistribution charity position food safety? It does not distribute past-

562 date food, reflecting concerns around donor compliance but also about the quality and

563 reputational implications of redistributed food. Following a briefing paper suggesting

564 the "inferior choice, accessibility and (nutritional) quality" of redistributed surplus

565 food (Caraher \& Furey, 2017:13), the charity communicated via social media that it

566 distributes nutritious, in-date, desirable food. Staff frequently emphasised that it

567 delivered food to organisations cooking meals rather than giving food bags,

568 emphasising provision of commensal, familial, 'proper' food. Redistributing fresh

569 produce was described as a way to provide healthy-yet-compliant food, with loose

570 produce not requiring an expiry-date. This non-requirement lends space for more

571 contextual practice; warehouse manager Graham maximised the opportunities it

572 afforded for removing packaging. He argued that much produce comes in "its own

573 packaging" and can be sorted by its sensory qualities. He combined concern for

574 preserving recipients' dignity by providing fresh, high-quality food with skills to

575 predict temporalities of fresh produce's capacity to degrade:

[charity clients] don't want fruit and veg sorted to a low standard...four days later we finally get it to the customer and the next day...they open the cupboard... and go "why have they given me a bag of mush?" It's gotta be good standards from the start, and it's respect as well. You're feeding people in needoh, here's some rotten old crap for you...(Graham, interview, 14/11/2016)

581 The inferred 'neediness' of eventual food recipients was thus invoked in justifying

582 sorting practices that required volunteers to follow expiry-dates but also their

583 embodied skill in knowing food in its present and predicted future state. Unlike the

584 school programme, the charity model does not permit such close engagement

585 between redistributors, eventual eaters and the visceral affordances of food. However,

586 Graham and other food sorters' care-ful praxis suggests that eventual eaters' sensory 
587 experiences were indeed a concern that commanded volunteers' own embodied and 588 sensory labours.

\section{Affective assemblages as politics?}

590 How might we analyse these multiple positionings of food and children politically?

591 The activist network taught food materialities as contextual and systemic, involving 592 visceral contact with food items and cognitive learning about food systems, safety and

593 health. Classroom sessions constituted amalgams of images, imaginings, narratives,

594 and tactilities, glued together by the intimate group setting and atmosphere of 595 excitement. This recalls Bennett's conceptualisation of 'vibrant matter' as 'conative 596 bodies', from whose mutually “confederate agency" new sympathies between bodies 597 might arise (Bennett, 2010). Bennett locates political action in the emergence of 598 publics, "groups of bodies with the capacity to affect and be affected", whose 599 experience/articulation of shared harms prompts engagement in "new acts that will 600 restore their power", albeit with unpredictable consequences (2010:101). Similarly, 601 volunteers sorting food in charitable spaces expressed affective and discursive re602 learnings of food with potential consequences both for eventual eaters and their own 603 foodscapes. Politics viewed thus is immanent in the micro-encounter of intimate 604 person-food relating as well as systemic knowledge and policy change. Crafting close 605 encounters for children and food lends space for a processual, more distributed kind 606 of ethics than the charitable ethic of giving/receiving based on a narrow 607 conceptualisation of 'need', recalling a Foucauldian distinction between ethics and 608 morality (Foucault, 1997).

609 While inferring potential for 'vibrant encounters' to transform children's intimate 610 relationships with food, different children may not experience the same 'participatory' 611 space in the same way (Kraftl, 2013:15). Activist-educators tended to problematise 612 children's/families food choices and behaviours as sites for transformation, hoping 613 that this might galvanise future activism towards eliminating food waste. Meanwhile, 614 however, structural limitations upon foodscapes persist: neighbourhood deprivation, 615 food access and immigration status among others. Families' capacities to join/form 616 'groups of bodies' united against the 'shared harms' of wasted food and hunger require, 617 first and foremost, their acquiring adequate food and other resources to metabolise 618 social reproduction. Bennett's theorisation of the political promise of more-than- 
619 human confederacies challenges the instrumentalising of matter (including food) that

620 "feeds human hubris and our earth-destroying fantasies of conquest and consumption"

621 (2010:ix). This injects ecological hope into efforts to nurture more vibrant person-

622 food relationships through food redistribution. However, it obscures humans' different

623 propensities for hubris, where such 'fantasies of...consumption' may emerge from

624 experiencing prolonged deprivation. PEB's attention to political-economic structures

625 is here recalled, in recognition of the ever-urgent task of countering welfare

626 retrenchment and systemic inequality. The distinctive political ontology of Bennett

627 and others' materialism is hard to reconcile with a Marxist critique. However,

628 embracing both, we can see wasted food redistribution as meeting bodily needs and

629 potentially instigating political action at unexpected sites, shedding light on diverse

630 forms of uneven urban development whose transformation might prevent growing

631 reliance on food charity and projects dependent on unsustainable supplies of surplus

632 food.

\section{Conclusion}

634 Our analysis suggests that activist-educators and charity redistributors drew upon 635 both visceral and regulatory techniques for distinguishing food from waste. Haptic, 636 gustatory, olfactory, visual and even auditory engagements with food allowed both 637 activist and charity volunteers to separate food from the beyond-the-pale in an effort 638 to redistribute 'good' food. Wasted food's journey is mediated by complexes of 639 bodies, infrastructures, regulations, practices and discourses that escape the 640 activist/charity binary. The PEB framework acknowledges structural, discursive and 641 material factors not as separate but interacting. Expiry-dates are determined by law 642 and corporate production processes, but learners and educators' knowledge and 643 attitudes towards their relevance vary for diverse reasons. Sensual engagement with 644 food may accompany attention to expiry-dates, while embodied practices of cutting, 645 cooking and storing food interact with such cognitive attention and regulatory 646 rendering of responsibility for food management.

647 We have presented tensions between ethical possibilities opened up by close 648 engagement with wasted foods and the risks of prioritising individual food choices as 649 a means to address hunger/waste. While activists sought to redefine ex-commodified 650 food as vibrant matter through which to kindle new, potentially-transgressive kinds of 
651 food-body knowing, the charity's purpose in handling food was not only based on 652 engagement with recipients but also to maintain donor compliance and justify a 653 reputation as providing adequate food. On the other hand, the diverse organisations 654 receiving the charity's food could be using it for radical community work, from 655 feeding unmet needs for food to fostering networks of solidarity at different 656 'community' scales including national and global campaigns.

657 Food not only is connection, but does connecting, and both activist and charitable 658 redistribution makes such connections possible. However, the charity's public-facing 659 emphasis on growing quantities redistributed or people fed suggests its lack of 660 engagement with food's resonant qualities and affordances for critiquing/transforming 661 food systems. The school programme, while it risks being perceived as another form 662 of charitable food assistance, created collective spaces for reflecting upon food and its 663 systemic transformations and possibilities. Food waste pedagogies could potentially 664 go beyond de-fetishising food, towards interrogating human fascinations with food 665 commodities and their consumption (Bennett, 2001) and recognising 'reflexive 666 consciousness' of the ethical food consumer as a classed modality (Guthman, 2003).

667 Ultimately, wasted food redistribution reflects and responds to deep economic 668 imbalances. Redistribution actors' knowledge of injustices affecting the communities 669 they feed constitutes vital grounds for redistribution practices that nourish minded670 bodies, public critique and, through reflexive alliance-building, transform food 671 (re)distribution structures.

672 References

673 APPG on School Food. (2015). Filling The Holiday Gap: Update Report 2015. 674 Available at:

676 Barnard, A., \& Mourad, M. (2014). What's So “Contentious” About Free Food?

677 Tactical Repertoires and Food Waste Activism in the U.S. and France. Available 678 at: https://oxthepunx.files.wordpress.com/2010/11/barnard-mourad-whats-so679 contentious-about-free-food-asa-submission.pdf

680 Barnard, A. (2016). Freegans: Diving into the wealth of food waste in America. 681 Minneapolis: University of Minnesota Press. 
682 Belfrage, C., \& Hauf, F. (2017). The Gentle Art of Retroduction: Critical Realism, 683 Cultural Political Economy and Critical Grounded Theory. Organization Studies, $68438(2), 251-271$.

685 Bennett, J. (2001). The Enchantment of Modern Life. Princeton University Press.

686 Bennett, J. (2010). Vibrant Matter: A political ecology of things. Duke University 687 Press.

688 Biltekoff, C. (2016). The Politics of Food Anti-Politics. Gastronomica, (Winter).

689 Brembeck, H., et al. (2013). Exploring children's foodscapes. Children's

690 Geographies, 11(1), 74-88.

691 Caraher, M., \& Furey, S. (2017). Is it appropriate to use surplus food to feed people 692 in hunger? Short-term Band-Aid to more deep-rooted problems of poverty. Food 693 Research Collaboration.

694 Evans, D. (2014). Food Waste: Home Consumption, Material Culture and Everyday 695 Life. London: Bloomsbury.

696 Foucault, M. (1997). The ethics of the concern of the self as a practice of freedom. In 697 P. Rabinow (Ed.), Ethics: Subjectivity and Truth. Penguin.

698 Giles, D.B. (2016). The work of waste-making: biopolitical labour and the myth of 699 the global city. In Marshall \& Connor (Eds.), Environmental change and the $700 \quad$ world's futures: ecologies, ontologies and mythologies. Abingdon: Routledge.

701 Guthman, J. (2003). Fast food/organic food: Reflexive tastes and the making of 702 'yuppie chow. Social \& Cultural Geography, 4(1), 45-58.

703 Haraway, D. (1988). Situated Knowledges: The Science Question in Feminism and 704 the Privilege of Partial Perspective. Feminist Studies, 14(3), 575.

705 Hayes-Conroy, A. (2017). Better than text? Critical reflections on the practices of 706 visceral methodologies in human geography. Geoforum, 82(April), 51-52.

707 Hayes-Conroy, A. \& J. (2015). Political ecology of the body: a visceral approach. In 708 R. L. Bryant (Ed.), The International Handbook of Political Ecology (pp. 650709 672). Cheltenham: Elgar.

710 Hayes-Conroy, J., \& Hayes-Conroy, A. (2013). Veggies and visceralities: A political 
ecology of food and feeling. Emotion, Space and Society, 6(1), 81-90.

712 Henderson, G. (2004). "Free" food, the local production of worth, and the circuit of 713 decommodification: A value theory of the surplus. Environment and Planning D: $714 \quad$ Society and Space, 22(1), 485-512.

715

716

717

718

719

720

721

722

723

724

725

726

727

728

729

730

731

732

733

734

Heynen, N. (2009). Bending the Bars of Empire from Every Ghetto for Survival: The Black Panther Party's Radical Antihunger Politics of Social Reproduction and Scale. Annals of the Association of American Geographers, 99(2), 406-422.

Heynen, N. (2010). Cooking up Non-violent Civil-disobedient Direct Action for the Hungry: "Food Not Bombs" and the Resurgence of Radical Democracy in the US. Urban Studies, 47(6), 1225-1240

Heynen, N. (2013). Urban political ecology I: The urban century. Progress in Human Geography, 38(4), 598-604.

Huey P. Newton Foundation. (2008). The Black Panther Party: Service to the People Programs. (Hilliard, Ed.). Albuquerque: University of New Mexico Press.

Joseph Rowntree Foundation. (2017). UK Poverty 2017. Available at: https://www.jrf.org.uk/report/uk-poverty-2017

Kraftl, P. (2013). Beyond "voice",beyond "agency", beyond "politics”? Hybrid childhoods and some critical reflections on children's emotional geographies. Emotion, Space and Society, 9, 13-23.

Lyndhurst, B. (2008). Research into consumer behaviour in relation to food dates and portion sizes. Banbury: WRAP. Available at: http://www.wrap.org.uk/sites/files/wrap/Consumer behaviour food dates, portion sizes report july 2008.pdf

Midgley, J. (2013). The logics of surplus food redistribution. Journal of Environmental Planning and Management, 57(12), 1872-1892.

Milne, R. (2012). Arbiters of waste: date labels, the consumer and knowing good, safe food. The Sociological Review, 60, 84-101.

Mourad, M., \& Barnard, A. (2016). Fighting food waste with dumpster dinners. Discover Society, (36). Available at: https://discoversociety.org/2016/09/06/on- 
the-frontline-fighting-food-waste-with-dumpster-dinners/

741 Patel, R. (2011). What the Black Panthers can teach the US food movement. In S. Amin (Ed.), Food Movements Unite! Strategies to Transform Our Food System. Food First Books.

Poppendieck, J. (1998). Sweet Charity? Emergency Food and the End of Entitlement.

Reverdy, C. (2011). Sensory Education: French Perspectives. In Preedy,Watson, \& Martin (Eds.), Handbook of Behavior, Food and Nutrition (pp. 143-157). New York: Seven Stories Press.

Shove, E. (2010). Beyond the ABC: Climate change policy and theories of social

Tarasuk, V., \& Eakin, J. (2005). Food assistance through "surplus" food: Insights from an ethnographic study of food bank work. Agriculture and Human Values,

754 Thrift, N. (2004). Intensities of feeling: Towards a spatial politics of affect.

Van der Horst, H., Pascucci, S., \& Bol, W. (2014). The "dark side" of food banks? Exploring emotional responses of food bank receivers in the Netherlands. British Food Journal, 116(9), 1506-1520. 